DIW BERLIN

Discussion

Papers

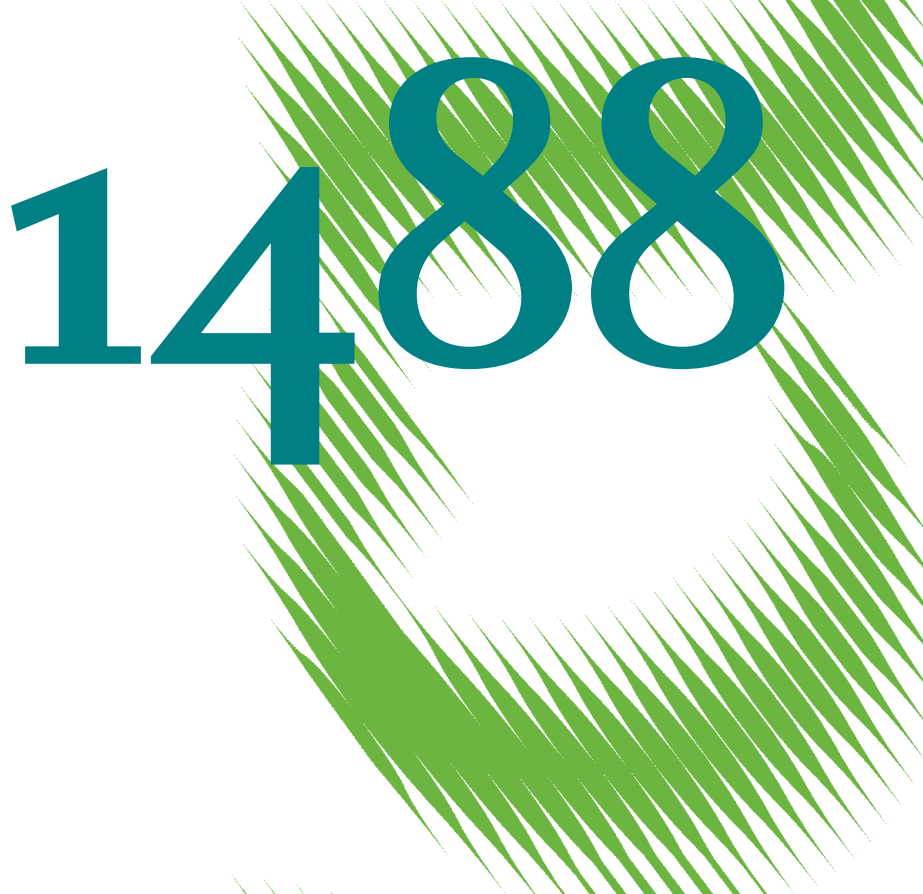

The Ruble between the Hammer and the Anvil: Oil Prices and Economic Sanctions 
Opinions expressed in this paper are those of the author(s) and do not necessarily reflect views of the institute.

IMPRESSUM

(C) DIW Berlin, 2015

DIW Berlin

German Institute for Economic Research

Mohrenstr. 58

10117 Berlin

Tel. +49 (30) $89789-0$

Fax +49 (30) $89789-200$

http://www.diw.de

ISSN electronic edition 1619-4535

Papers can be downloaded free of charge from the DIW Berlin website:

http://www.diw.de/discussionpapers

Discussion Papers of DIW Berlin are indexed in RePEc and SSRN:

http://ideas.repec.org/s/diw/diwwpp.html

http://www.ssrn.com/link/DIW-Berlin-German-Inst-Econ-Res.html 


\title{
The Ruble between the hammer and the anvil: Oil prices and economic sanctions
}

\section{Christian Dreger, Jarko Fidrmuc, Konstantin Kholodilin, Dirk Ulbricht ${ }^{1}$}

\begin{abstract}
The exchange rate fluctuations strongly affect the Russian economy, given its heavy dependence on foreign trade and investment. Since January 2014, the Ruble lost $50 \%$ of its value against the US Dollar. The fall of the currency started with the conflict between Russia and Ukraine. The impact of the conflict on Russia may have been amplified by sanctions imposed by Western countries. However, as Russia is heavily dependent on exports of natural resources, the oil price decline starting in Summer 2014 could be another factor behind the deterioration. By using high frequency data on nominal exchange and interest rates, oil prices, actual and unanticipated sanctions, we provide evidence on the driving forces of the Ruble exchange rate. The analysis is based on cointegrated VAR models, where fundamental long-run relationships are implicitly embedded. The results indicate that the bulk of the depreciation can be related to the decline of oil prices. In addition, unanticipated sanctions matter for the conditional volatility of the variables involved.
\end{abstract}

Keywords: Military conflict, sanctions, oil prices, Ruble depreciation

JEL Classification: C22, F31, F51

\footnotetext{
${ }^{1}$ Dreger: German Institute for Economic Research (DIW Berlin), Mohrenstraße 58, 10117 Berlin, Germany, cdreger@diw.de;

Fidrmuc: Zeppelin University, Friedrichshafen, Germany, jarko.fidrmuc@zu.de,

Kholodilin: DIW Berlin, kkholodilin@diw.de,

Ulbricht: DIW Berlin, dulbricht@diw.de.
} 
The exchange rate fluctuations strongly affect the Russian economy, given its heavy dependence on commodity exports, foreign investment and imports of consumer goods. Since January 2014, the currency depreciated from about 33 Ruble for 1 USD to its lowest value of nearly 70 Ruble at end of January, and it did not appreciate below 50 Ruble for 1 USD so far. Thus, the Ruble lost $50 \%$ or more of its value against the US Dollar. The evolution of the Ruble exchange rate with respect to the Euro is similar (Figure 1). In the most recent period, the Ruble recovered a bit faster in Euro terms, due to the Euro depreciation against the US Dollar. The fall of the Ruble might be related to economic sanctions against Russia implemented by Western countries to force Russia to return to the status quo before the conflict with the Ukraine. The strong linkages to the Russian economy can likely explain the subsequent decline of currencies of most countries belonging to the Commonwealth of Independent States. While these developments are overwhelming, they are more dramatic for the Ukraine. Actually, the Hryvnia lost two thirds of its initial value. Dreger and Fidrmuc (2011) discuss the role of the Russian factor in the earlier evolution of the GUS exchange rates.

-Figure 1 about here-

Many politicians argued that the introduction of sanctions are appropriate to dry up the military conflict, as they put high economic pressure on Russia. However, the world prices for oil and other natural resources have also fallen since Autumn 2014, partially because of the modest expansion of demand in main industrial countries and lower growth perspectives in huge emerging markets, such as China and Brazil. Oil supply factors have also been crucial for the development, including the OPEC decision to maintain high production levels and the steady increase in oil production from the non-OPEC states, especially in the US due to technological advances. This paper investigates the relative role of political and economic factors in the deterioration of the Ruble. The exchange rate is intimately related to the economic performance of Russia.

Russia is one of the leading suppliers of oil and gas in the world economy. At the same time, industrial diversification is not highly developed. For example, two thirds of total exports and more than $50 \%$ of the budget revenues depend on oil and gas. The strong reliance on com- 
modity exports makes the country extremely vulnerable to shifts in global prices. While GDP growth exceeded $7 \%$ in most years of accelerating oil prices before the financial crisis, the expansion afterwards was modest, due to lower prices for natural resources and increasing difficulties to attract foreign direct investment. Because of the depreciation of the Ruble, growth prospects worsened further. The currency losses led to collapsing government revenues, lower public spending and increasing inflation spurred by higher import prices. Non-oil exports did not benefit much, as the manufacturing sector is still incompetitive in international markets. Sectoral sanctions may have accelerated the downturn, particularly measures that dry up Russian banks' sources to refinance external debt. This also affects the Russian state, which has already started to tap the reserve funds built up during periods of resource price booms. If the oil price remains low and sanctions are maintained, a serious erosion of reserves is expected, with further consequences on the ability of the government to meet its obligations in a wide range of fields, including pensions and other social securities as well as the military budget. Restrictions on technology transfer in the energy industry endanger the ability of Russian firms to explore new oil fields and expand production. The Russian central bank raised its policy rate several times to fight inflation and capital outflow. This caused further downward pressure on domestic consumption and investment. International confidence that the Russian government can repay its debts eroded, pushing up the sovereign yields to new heights. Against this background, the economic outlook points to a deep recession in Russia for the years ahead. But it is still unclear to what extent the economic sanctions against Russia or the persistent fall in oil prices are the driving forces behind the evolution. Evidence on the relative role of the two factors is highly relevant for policy advice.

Since national accounts data are limited due to publication lags and low reporting frequencies it is difficult to separate the impact of sanctions from the hit due to the slump in oil prices. However, evidence can be built upon exchange rate movements. Due to the daily frequency of the variables, the econometric analysis can refer to a rather short period, i.e. the duration of the conflict without running into degree of freedom problems. Based on impulse response analysis and variance decomposition, the results indicate that the bulk of the exchange rate depreciation can be attributed to declining oil prices. In addition, unanticipated component of sanctions matter for the conditional volatility of the variables involved.

The rest of the paper is organized as follows. In Section 2, the main stages of the political conflict between Russia and the Ukraine are reviewed. Section 3 discusses the economic impact of 
sanctions and measures that have been implemented during the recent year. Section 4 presents the information provided by the media. The usage of media data is rather novel in the literature on sanctions. Actual sanctions and news on the conflict are distinguished (Section 5). Econometric results are presented in Section 6. Finally, Section 7 concludes with some policy implications.

\section{Evolution of the military conflict}

In the last decades, Ukraine has been suffering from insufficient and protracted economic reforms, high level of corruption, unclear economic policies, rent seeking, oligarchic industrial structure, but also from a disadvantageous geographical location between Russia and European Union. Reflecting a high dependency from Russia especially regarding energy imports, unwillingness of political elites to introduce the acquis communautaire, the country stayed out from the EU enlargement process in its several neighboring countries. In addition, the halt of Eastern enlargement of the EU at the Ukrainian border reflected a lack of interests in Western countries to integrate a large and weak economy which was generally seen as a part of the Russian dominance area. These factors have been slowly changing. The EU offered a Stabilization and Association agreement to Ukraine in 2008, which was commonly criticized on the ground that it offered worse conditions to Ukraine than previous association agreements for Central and Eastern European countries. The ratification of the agreement has been delayed by numerous political factors, such as the sentencing of the former prime minister Yulia Tymoshenko.

Finally, the former president Yanukovych refused to sign the agreement. Instead, he agreed on tighter cooperation with Russia, in exchange for financial loans and lower gas prices. These steps have been seen as an ultimate stop to all economic reforms. This prospect caused mass protests by the Ukrainian population, well-known as the Euromaidan movement. The protests culminated in the February 2014 revolution which removed the Yanukovych regime and established a pro-Western interim government.

The developments escalated to a new stage in Spring 2014. Russia stopped financial support to Ukraine. At the same time, pro-Russian demonstrations started in East Ukrainian regions with mainly Russian speaking population. During this unrest, the Crimean peninsula was annexed by the Russian Federation in March. Riots escalated into an armed conflict between separatist 
forces supported by Russia and the pro-Western Ukrainian government. The areas of Donetsk and Lugansk, in the center of the coal-producing Donbass region, declared their independence and cut ties with the central government in Kiev. In response, the Ukrainian government started a military offensive that was successful only initially. Given a massive Russian assistance the separatists kept or regained much of the territory they had lost. During the combats in Donbass, a Malaysian passenger flight from Amsterdam was shot down in July 2014, killing all people on board including numerous Western European (especially Dutch) tourists.

The last phase of the conflict can be attributed to attempts to stabilize the situation at the current stage. A deal for a ceasefire, the Minsk agreement, was signed in September, but violations were common. Heavy fighting resumed across the conflict zone, including the Donetsk International Airport and the city of Debaltseve, which was conquered by the separatists. A new ceasefire agreement, called Minsk II, was signed in February 2015. While the Minsk II agreement has been quite successful at least to stop a further escalation of the conflict in East Ukraine, it did not help to solve the political and economic problems. East Ukraine is now becoming a lawless region without international recognition. It is likely that the region will develop to the so called frozen conflict zone similar to Transnistria ${ }^{2}$. While the economic future of this area is highly questionable, its existence will most likely impose also significant long-term economic losses to Ukraine and possibly to Russia. This will hamper the prospects for growth in both countries.

Multiple elections were held over the course of the crisis. In May 2014, the new Ukranian president Petro Poroshenko came into power. The first post-revolutionary parliamentary elections in Ukraine took place in October and confirmed the Western orientation of the interim government. The separatists conducted their own polls in November. They were supported by Russia, but largely denounced by Western countries.

To increase the incentives to sign a peace agreement, Western governments, most notably the US and the EU imposed sanctions against individuals and firms in Russia and the Ukraine over the whole duration of the crisis. These sanctions started with the annexation of the Crimea and were gradually sharpened as the conflict continued. Initially, Western Sanctions include travel bans and the freezing of assets of individuals. Sectoral sanctions like restrictions on gov-

\footnotetext{
${ }^{2}$ Transnistria is a breakaway region located at the Eastern border of Moldavia with Ukraine. Since the War of Transnistria in 1992, it is a stagnating economy, which is fully dependent on aid flows from Russia.
} 
ernment-owned Russian banks or trade restrictions related to the Russian energy and defence sector have been added at later stages. Russia responded with restrictions to several countries, including a ban of food imports from the USA, the EU, Canada, and Australia and travel restrictions for certain Western citizens. More serious measures can be on the agenda on both sides, like the exclusion of Russia from the international payments system or the refusal of overflying rights over Russia for Western airlines. Their implementation depends on the future evolution of the conflict.

\section{$3 \quad$ Economic impact of sanctions}

According to Hufbauer, Elliott, Oegg and Schott (2007), among others, several stages of sanctions can be distinguished. The weakest forms refer to diplomatic sanctions, such as the withdrawal of ambassadors and the suspension of international negotiations. The next stage includes measures targeting individual citizens and companies, such as travel bans, asset freezes, stop of development aid and obstacles to get credit from international organizations. Sanctions against specific industrial sectors, such as trade restrictions and embargoes constitute the strongest form. In any case, sanctions may include a smart component. For example, asset freezes and travel bans only hit a certain group of people or companies. All stages of sanctions have been implemented by Western governments starting from the annexation of the Crimea. As part of the diplomatic measures, Russia was excluded from the G8 meetings, and bilateral talks on cooperation agreements and visa regulations were suspended. With the ongoing conflict, measures against Russian and Ukrainian individuals and legal entities have been implemented. Restrictions to particular industries focus on banking, energy and defence sectors. For example, the USA prohibited any commercial relations between US citizens or firms and the sanctioned companies, most important Bank Rossiya, SMP Bank and Volga Investment. The USA also banned the export of certain technology goods that could be used for military purposes.

The empirical evidence on the effectiveness of economic sanctions is mixed. Trade restrictions, for instance, can raise the costs for the target country, but may also harm the sanctioning country. Countries with strong economic ties are especially hit through lower growth perspectives. Therefore, it is not surprising that the measures actually adopted appear to be ineffective in many cases. While some studies found that smart sanctions are effective (Morgan and 
Schwebach, 1995, Cortright and Lopez 2000), others found that only harsh measures may trigger a significant impact on policies (Lam 1990, Hufbauer and Oegg 2003). In addition, the process of designing sanctions is inherently shaped by powerful groups in the sanctioning countries that serve their own interest (Kaempfer and Lowenberg, 1988). Game-theoretic models suggest that the success of sanctions further depends on conflict expectations and the levels of commitment. Many sanction end as a threat, without actually being implemented (Kaempfer and Lowenberg, 2007).

The impact of sanctions can be measured in terms of economic effects, but also in terms of their policy impact, i.e. sanctions are considered to be successful if they have led to the desired policy change. By examining a huge set of sanctions, Hufbauer, Elliott, Oegg and Schott (2007) concluded that about one third of them have been successful, at least partially. However, this number is likely exaggerated. If one controls for the direct or indirect use of military forces and for the fact that the target country does not make the concessions initially asked for, the share of successful sanctions is significantly lower. In addition, the success rate decreases if the aim of the sanctions is more ambitious, such as a major policy change. Kaempfer and Lowenberg (2007) stressed the role of the target size. Larger and self-sufficient countries are able to absorb sanctions more easily than smaller economies. Using a gravity regression approach, Caruso (2003) reported negative effects of economic sanctions on trade. Sanctions may cause higher damage, if they are implemented multilaterally. In case of unilateral sanctions, the target might be able to sell or buy goods and raw materials from third, nonsanctioning countries. Furthermore, sanctions fail more likely if there is substantial third party assistance to the target (Bonetti, 1998). Based on a simultaneous equation approach, Jing, Kaempfer and Lowenberg (2003) argued that the success of sanctions is positively correlated with the degree of warmth in the relations between sanctioner and target prior to the sanctions, negatively with the size of the sanctioner relative to the target, and negatively with the economic health and political stability of the target.

\section{$4 \quad$ Media information and economic analysis}

In order to assess the impact of sanctions vis-à-vis the oil price on the development of the economy, in addition to the hard data, we are using the evidence based on media information. As these data match the daily frequencies of exchange rates and oil prices, the analysis can be done in rather short time intervals without running into degree of freedom problems. Media 
information also allows to separate expected from unexpected policy outcomes, i.e., whether sanctions actually implemented were more or less severe than initially expected.

Due to the ever growing body of news and news channels, such as blogs, tweeds, and newsletters it is virtually impossible or at least prohibitively costly to explore the news by human analysts. Therefore, evidence is based on automated text search, i.e. a simple word count. In fact, such methods are widely applied to predict business cycles and financial markets. Most important, the $R$-word Indicator for the early detection of turning points of business cycles is published by The Economist since 1992. The indicator counts how often the word "recession" appears in the New York Times and the Washington Post. Doms and Morin (2004) created sentiment indicators based on the number of articles that contain certain keywords and phrases in the title or in the first paragraph in large US newspapers. The authors found that news media affect the perceptions of consumers, because they update their expectations about the economy much more frequently during periods of high news coverage than in periods of low news activities. News might cause temporary deviations from the path implied by economic fundamentals and can contribute to self-fulfilling tendencies. Kholodilin and Siliverstovs (2006) reported that media indicators are to some extent useful as predictors of the German GDP growth.

Based on observed psychological patterns, Barberis, Schleifer and Vishny (1998) developed a theoretical framework to explain investors' sentiment in asset markets. Tetlock (2007) looked at the interactions between the media and the stock market using daily information from the Abrest of the Market section of the Wall Street Journal. According to the results, high media pessimism can exert downward pressure on stock markets. News sentiment is extracted automatically counting the words in the General Inquirer's Harvard IV-4 Psychological Dictionary. The context of news can be relevant, e.g., negations like not good can invert the indication of a word. In addition, media data have been used in the analysis of exchange rates. By extracting the information from Reuters news wire reports, Dominguez and Panthaki (2006) concluded that news on macroeconomic fundamentals, but also non-fundamental news and order-flows matter for exchange rate returns and volatility. Laakkonen (2007) argued that macroeconomic news increase the volatility of the US-Dollar vis-à-vis the Euro. Asymmetric effects are likely, as US news tend to be more important than European news, and negative news seem to be more influential than positive ones. Furthermore, conflicting news increase exchange rate volatility more and faster than consistent news. 
The analysis is based on macroeconomic series, actual sanctions and information taken from the media.

\section{Macroeconomic time series}

Macroeconomic data used in this study are daily time series on nominal bilateral exchange rates of the Ruble against the US Dollar, the oil price in US Dollars per barrel, and interest rates for overnight loans in Rubles. See Figure 2 for the oil price and the interest rate. After achieving high plateau in the first half of the year, oil prices dramatically fell until the beginning of 2015. The RUONIA is used to be relatively stable at about $8.5 \%$, until December $16^{\text {th }}, 2015$, when the Central Bank of Russia drastically raised its policy rate from 10.5 to $17 \%$. In its press release Russian central bank justified the increase by a necessity to combat inflation and devaluation tendencies.

-Figure 2 and Table 1 about here-

\section{Composite sanction indices}

Based on the sanctions actually implemented against Russia and on Russian sanctions against Western countries, two composite indices

$$
S_{T}^{w}=\sum_{t=1}^{T} s_{t}^{w} \quad, \quad S_{T}^{r}=\sum_{t=1}^{T} s_{t}^{r}
$$

are constructed. The superscript $w$ denotes the sanctions implemented by Western countries, and $r$ refers to the Russian sanctions. The composite indices are defined as the cumulative sum of individual sanction dummies, $s^{w}$ and $s^{r}$. The dummies are equal to 1 if a sanction is in place in period $t$ and 0 otherwise. See Table 1 for a list of sanctions implemented over the course of the conflict.

Two modifications are considered to ensure the robustness of the results. First, sanctions can differ in terms of their harshness. They can be directed against individuals, specific entities or, most serious, against sectors of the economy. Second, their impact may vary across countries. 
For example, the effect of sanctions from Albania might be almost zero, while EU sanctions could exert a non-negligible impact on the Russian economy. Similar, the impact of the Russian sanctions might differ across the targeted countries. Hence, the weighted composite sanctions indices

$$
S_{T}^{w}=\sum_{t=1}^{T} \sum_{i=1}^{I} \sum_{j=1}^{J} w_{i}^{w} w_{j}^{w} s_{t i j}^{w} \quad, \quad S_{T}^{r}=\sum_{t=1}^{T} \sum_{i=1}^{I} \sum_{j=1}^{J} w_{i}^{r} w_{j}^{r} s_{t i j}^{r}
$$

control for both the severity of sanctions $(i)$ and the target country $(j)$. The weights $w_{\mathrm{i}}$ and $w_{\mathrm{j}}$ are based on the type of sanctions and trade shares with Russia, respectively. Country weights reflect the share of the individual country in Russia's external trade, averaged over the 20092013 period. Trade is measured as the sum of exports and imports and obtained from the UN Comtrade database. Composite sanction indices based on unweighted and weighted data are shown in Figure 3. The weighted series have a much lower level, due to small trade weights with Russia in many cases.

\section{Media indices}

As a measure of expectations on sanctions a news based index is constructed and decomposed into anticipated and unanticipated effects. The index reflects the frequency of the items containing information on Russia-related sanctions in the international media. It is constructed by the number of daily occurrences of the words "Russia" and "sanctions" in major printed media of eight countries (France, Germany, Italy, Russia, Spain, Ukraine, UK, and USA). A list of media sources and corresponding search words are exhibited in Table 2.

\section{-Figures 3 and 4 and Table 2 about here-}

To construct the composite news index the occurrences in national media are aggregated and normalized by the sum of occurences. Then, scaled country-specific indices are aggregated to obtain a composite news index as a simple average. The resulting index is display in Figure 4. As seen, before March 2014 it fluctuates near zero. Then, it goes up substantially and remains at high level till the end of our sample. It attains two major peaks in March and July 2014, when main sanctions packages were put in action. This index is cumulated over time to be 
consistent with the index on actual sanctions. Since the combinations of "Russia" and "sanctions" are not necessarily related to the conflict before the annexation of the Crimea, the composite news index is set to 0 until the end of February, 2014.

The news index can be seen as a measure of expectations about future sanctions and opinions on sanctions already in place. Without having access to the full media texts it is impossible to identify the context. Thus, the overall news index might give rise to biased results. In order to extract expectations on sanctions from the complex mess, the news index is regressed upon the leads of the composite sanction indices, i.e.,

(3) $\quad C_{T}=\beta_{0}+\sum_{\tau=1}^{L^{w}} \beta_{\tau} S_{T+\tau}^{w}+\sum_{\tau=1}^{L^{r}} \theta_{\tau} S_{T+\tau}^{r}+u_{T}$

where $u$ is the error term. Leads $\tau$ for Western and Russian sanctions are included up to certain maxima $L^{w}$ and $L^{r}$ determined by the Schwartz-Bayes information criterion. The fit would be perfect in case when the sanctions have been correctly anticipated by the market. Therefore, the residuals are a measure of the bias introduced by the media. Both anticipated and unanticipated sanctions can exert an impact on the evolution of exchange rates. For instance, if the international press expects more extensive sanctions than decided, an overshooting of the Ruble exchange rate might be implied.

\section{$6 \quad$ Econometric analysis}

The variables include the Ruble exchange rate against the US Dollar, the oil price, and composite indicators on sanctions against and from Russia. The unexpected component of the sanctions is constructed from the residuals of equation (3). Since the Central Bank of Russia reacted several times to soften the depreciation of the Ruble, the RUONIA (Ruble OverNight Index Average), which is the Russian interbank rate for overnight loans, is also included. The variables are reported at the daily frequency over the period from January $1^{\text {st }}, 2014$ to March $31^{\text {st }}, 2015$. Exchange rates and oil prices are transformed in logs. Sanctions are count variables, if they are unweighted and real numbers if weighted. Finally, the RUONIA is given as a percentage ${ }^{3}$.

\footnotetext{
${ }^{3}$ The results shown in this section are based on the model version with unweighted sanctions. However, the evidence is very similar if weighted sanctions are used instead. The results can be obtained from the authors upon request.
} 
Inference is based on (generalized) impulse responses and variance decomposition. However, all variables are integrated of order 1, I(1), except for the unexpected component of sanctions, which is stationary (ADF=-7.79, $p$-value $=0.000$ ). To rule out spurious effects, cointegration should hold between the I(1) variables. According to the Johansen (1995) trace test, a single cointegration vector exists, see Table 3. The long run parameters are well signed. In equilibrium, a rise in the oil price and an increase in the RUONIA will lead to a decline of the Ruble value, i.e. an appreciation against the US-Dollar. The implementation of Western sanctions is accompanied by a Ruble depreciation, while Russian sanctions can compensate this effect.

-Table 3 about here-

The exchange rate elasticity with respect to the oil price exceeds unity, underpinning the important role of the oil price. Compared to this effect, the impacts of the other variables appear to be of minor relevance and for sanctions only significant at the margin. This finding suggests that the oil price dominates the sanctions to explain the actual Ruble evolution. Tests on weak exogeneity reveal a reasonable adjustment pattern. In particular, the feedback coefficient of the Ruble is highly significant, and its negative sign indicates error correction behavior. Hence, the cointegrating relationship might be interpreted as an equation determining the Ruble. Neither oil prices nor sanctions move to restore the long run. Oil prices are determined in international commodity markets and sanctions by the political process. The hypothesis of joint exogeneity of the three variables cannot be rejected $\left(\chi^{2}(3)=3.64, p\right.$-value 0.303$)$. After implementing the restrictions, the parameter estimates show only small changes.

Due to the cointegration result, the VAR can be evaluated in levels. In this setup, the long-run relationship is implicitly embedded (Sims, Stock and Watson, 1990). As a potential drawback, the multipliers are dominated by stochastic trends. Therefore, and to save degrees of freedom, unexpected sanctions are not considered in the impulse responses. But, as discussed below they can be relevant for the stationary VAR component. The impulse responses refer to the five-variables system (Figure 5). Because of multicollinearity, many of the VAR coefficients are insignificant at conventional levels. As suggested by Sims and Zha (1999), one standard error bands are preferred. 
While a rise in oil prices and an increase in the RUONIA will trigger an appreciation of the Ruble against the US Dollar, the currency is quite robust against shocks arising from the sanctions series. There is a minor positive impact stemming from the Russian sanctions. Combined with the cointegration evidence, this might imply some overshooting of the exchange rate in the short run. However, the effect is significant only at the margin. As a response to a Ruble depreciation, the oil price is expected to decline for a few weeks, putting less pressure on the Ruble. Again, this response might point to some kind of overshooting of the exchange rate and error correction behaviour afterwards. In addition, a depreciation of the Ruble causes an increase of the RUONIA which is broadly in line with the policy pursued by the Central Bank of Russia. At least to some extent, the policy was successful, as shown by the response of the Ruble to interest rate shocks. Moreover, as higher oil prices put less pressure of the Ruble, monetary policy will become less tight.

-Figure 5 about here-

The sanctions do not to play an important role for the other variables in the system, even if standard errors are less tolerant than usual. Spillovers between different types of sanctions are most striking. Sanctions against Russia will cause the implementation of sanctions against Western economies. An escalation spiral is not visible, as a positive response of Western sanctions is not detected.

According to the impulse responses, the oil price is much more relevant than the sanctions to explain the course of exchange rate levels. This finding is consistent with the decomposition of the forecast error variance, see Table 4. Own shocks account for a huge part of the forecast error, especially for the sanctions. As a rule the weight of the own shock declines with the forecasting horizon. For example, oil prices explain $8 \%$ of the Ruble after a week ( 5 days), but 12 percent after one month has passed. Only $1 \%$ of the variance of the Ruble forecast errors can be traced to sanctions, even after one month has passed.

Although the sanctions do not significantly alter the course of the Ruble, an impact may exist on exchange rate fluctuations. As the VAR length is optimized by the information criteria, the residuals of the system should fulfill the white noise properties or are at least stationary. Thus, the unconditional variance-covariance matrix is constant. This behavior, however, does not 
have implications on the development of the conditional moments. Conditional standard deviations could be related to unexpected sanctions, the latter generated according to equation (3).

-Table 4 about here-

Conditional moments can be estimated, if the cointegrated VAR in extended by a multivariate GARCH process, see Bauwens, Laurent and Rombouts (2006) for a survey of different specifications. Compared to univariate alternatives, the multivariate setup can control for spillovers across the equations. Besides the conditional variances, conditional covariances can be affected by unanticipated policies. However, the basic insights can be derived if the focus is on the variances ${ }^{4}$.

Equations describing the dynamics of the conditional variances of the VAR residuals are exhibited in Table 5. In addition to the GARCH(1,1) structure, the media index is allowed to drive the volatility of the respective variables. In addition to the potential contemporaneous impact of the media, a delay up to one week (five lags) is allowed. To improve the readability, irrelevant coefficients have been omitted. Reported effects are significant, at least at the margin $(20 \%$ significance level).

-Table 5 about here-

As a principal finding, GARCH effects are relevant in each case. The persistence is particularly striking for the Ruble and the oil price errors. In addition, the media do have an impact. While it is hardly significant at conventional levels for the Ruble and the RUONIA, the effects are more important for the oil price. If the sanctions turn out to be different than expected, additional volatility will be introduced in international commodity markets. As this might harm real economic growth, policy decisions should be as transparent as possible. Moreover, media af-

\footnotetext{
${ }^{4}$ Detailed results for the multivariate $\operatorname{GARCH}(1,1)$ model and conditional covariances can be obtained from the authors upon request.
} 
fect sanctions positively in the aggregate. Thus, if media expect more (less) severe sanctions than actually decided, policymakers are less (more) reluctant to further sanctions. Therefore, media reports have a self-fulfilling component. The results underpin that sanctions are influenced by past forecast errors regarding the political process. This effect is especially visible for Western sanctions, but also relevant for the Russian sanctions.

\section{Conclusions}

Due to its relative openness, the Russian economy is heavily exposed to exchange rate fluctuations. Since January 2014, the Ruble strongly depreciated against the US Dollar. The fall of the currency started with the conflict between Russia and Ukraine. The impact of the conflict on Russia may be amplified by the sanctions imposed by Western countries. However, oil prices also declined since Summer 2014. As Russia is heavily dependent on exports of natural resources, the oil price decline can be another factor behind the deterioration. By using high frequency data on nominal exchange and interest rates, oil prices, actual and unanticipated sanctions, we provide evidence on the driving forces of the Ruble exchange rate. The analysis is based on cointegrated VAR models, where fundamental long-run relationships are implicitly embedded. The results indicate that the bulk of the depreciation is caused by the decline of oil prices. In addition, unanticipated sanctions matter for the conditional volatility of the variables involved. 


\section{References}

Barberis N, Schleifer A, Vishny R (1998): A model of investor sentiment. Journal of Financial Economics 49, 307-343.

Bauwens L, Laurent S, Rombouts JVK (2006): Multivariate GARCH models: A survey, Journal of Applied Econometrics 21, 79-109.

Bonetti S (1998): Distinguishing characteristics of degrees of success and failure in economic sanctions episodes, Applied Economics 30, 805-813.

Caruso R (2003): The impact of international economic sanctions on trade: An empirical analysis, Peace Economics, Peace Science and Public Policy 9.2, Milan.

Cortright D, Lopez GA (2000): The sanctions decade: Assessing UN strategies in the 1990s. Lynne Rienner Publishers, Boulder.

Dominguez KME, Panthaki F (2006): What defines 'news' in foreign exchange markets, Journal of International Money and Finance 25, 168-198.

Doms ME, Morin NJ (2004): Consumer Sentiment, the Economy, and the News Media, Federal Reserve Bank San Francisco, Working Paper 2004-09.

Dreger C, Fidrmuc J (2011): Drivers of exchange rates in CIS countries: Evidence from a FAVAR analysis, Emerging Markets Finance and Trade 47, 49-58.

Engle RF, Kroner KF (1995): Multivariate simultaneous generalized GARCH, Econometric Theory $11,122-150$.

Hufbauer GC, Elliot KA, Oegg B, Schott, JJ (2007): Economic sanctions reconsidered. 3rd ed, Peterson Institute for International Economics.

Hufbauer GC, Oegg B (2003): The impact of economic sanctions on US trade: Andrew Rose's gravity model, Peterson Institute for International Economics, International Economics Policy Briefs, PB03-04.

Jing C, Kaempfer WH, Lowenberg AD (2003): Instrument choice and the effectiveness of international sanctions: A simultaneous equations approach, Journal of Peace Research 40, 519535. 
Johansen S (1995): Likelihood based inference in cointegrated vector autoregressive models. Oxford: Oxford University Press.

Kaempfer WH, Lowenberg AD (1988): The theory of international economic sanctions: A public choice approach, American Economic Review 78, 786-793.

Kaempfer WH, Lowenberg AD (2007): The political economy of sanctions, Handbook of Defense Economics Vol 2, Chapter 27.

Kholodilin KA, Siliverstovs B (2006): On the forecasting performance of alternative leading indicators for German GDP. Recent Evidence, Jahrbücher für Nationalökonomie und Statistik 226, 234-259.

Laakkonen H (2007): The impact of macroeconomic news on exchange rate volatility, Finnish Economic Papers 20, 23-40.

Lam SL (1990): Economic sanctions and the success of foreign policy goals: A critical evaluation, Japan and the World Economy 2, 239-248.

Morgan TC, Schwebach VL (1995): Economic sanctions as an instrument of foreign policy: The role of domestic politics, International Interactions 21, 247-263.

Sims CA, Zha T (1999): Error bands for impulse responses, Econometrica 67, 1113-1156.

Tetlock PC (2007): Giving content to investor sentiment: The role of media in the stock market, Journal of Finance 62, 1139-1168. 
Figure 1: Exchange rate of the Ruble in the crisis period

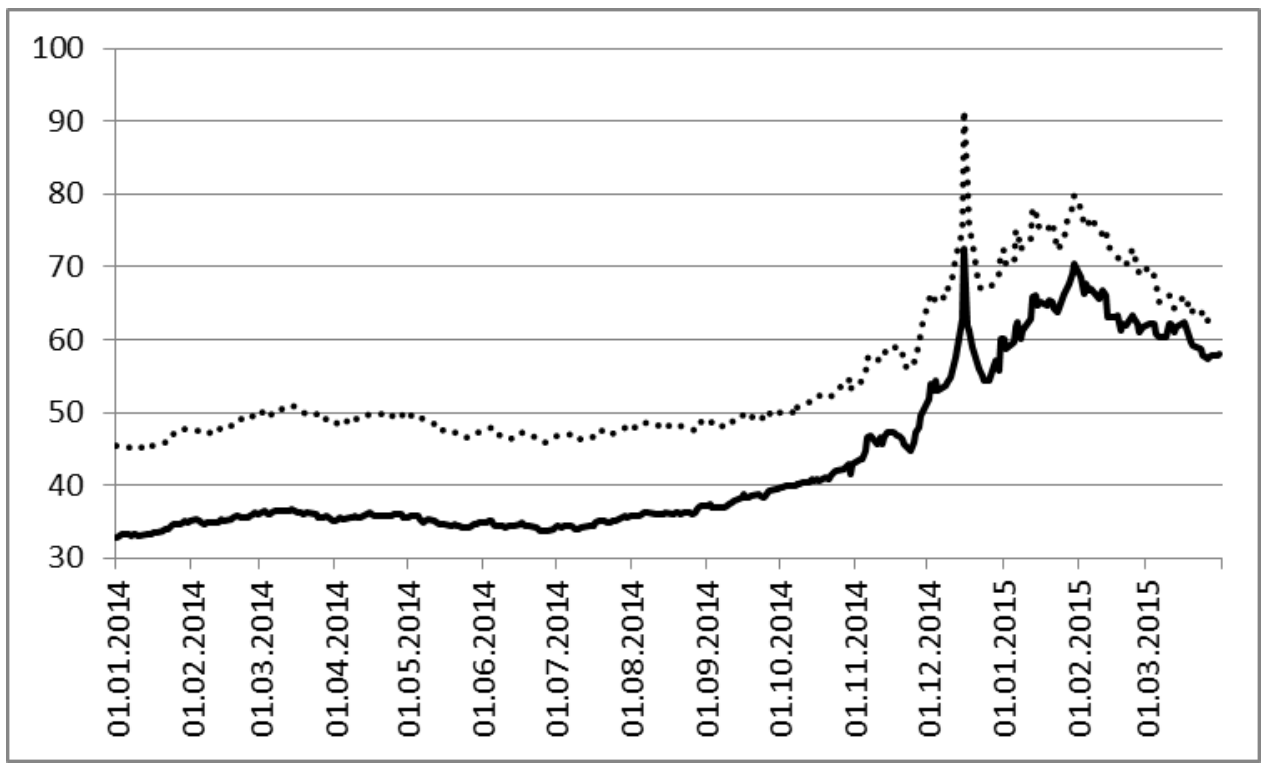

Note: Datastream. Ruble per Euro (dotted line) and in US Dollar. 
Figure 2: Oil prices (top) and interest rates (below)
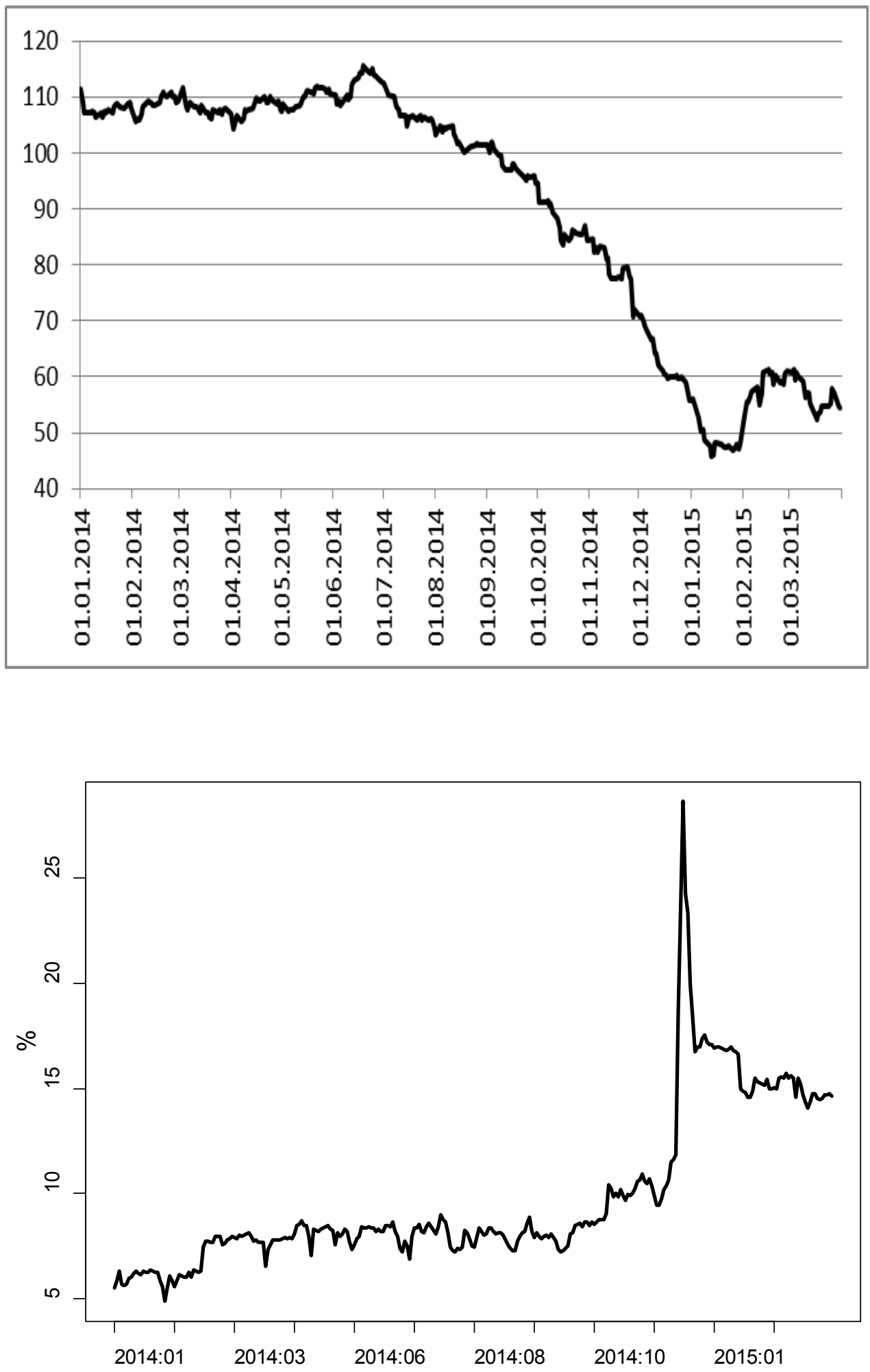

Note: Oil price (Brent) in USD per barrel taken from Datastream, RUONIA rate as a percentage obtained from the Central Bank of Russia. 
Figure 3: Composite sanction index, weighted (below) and unweighted
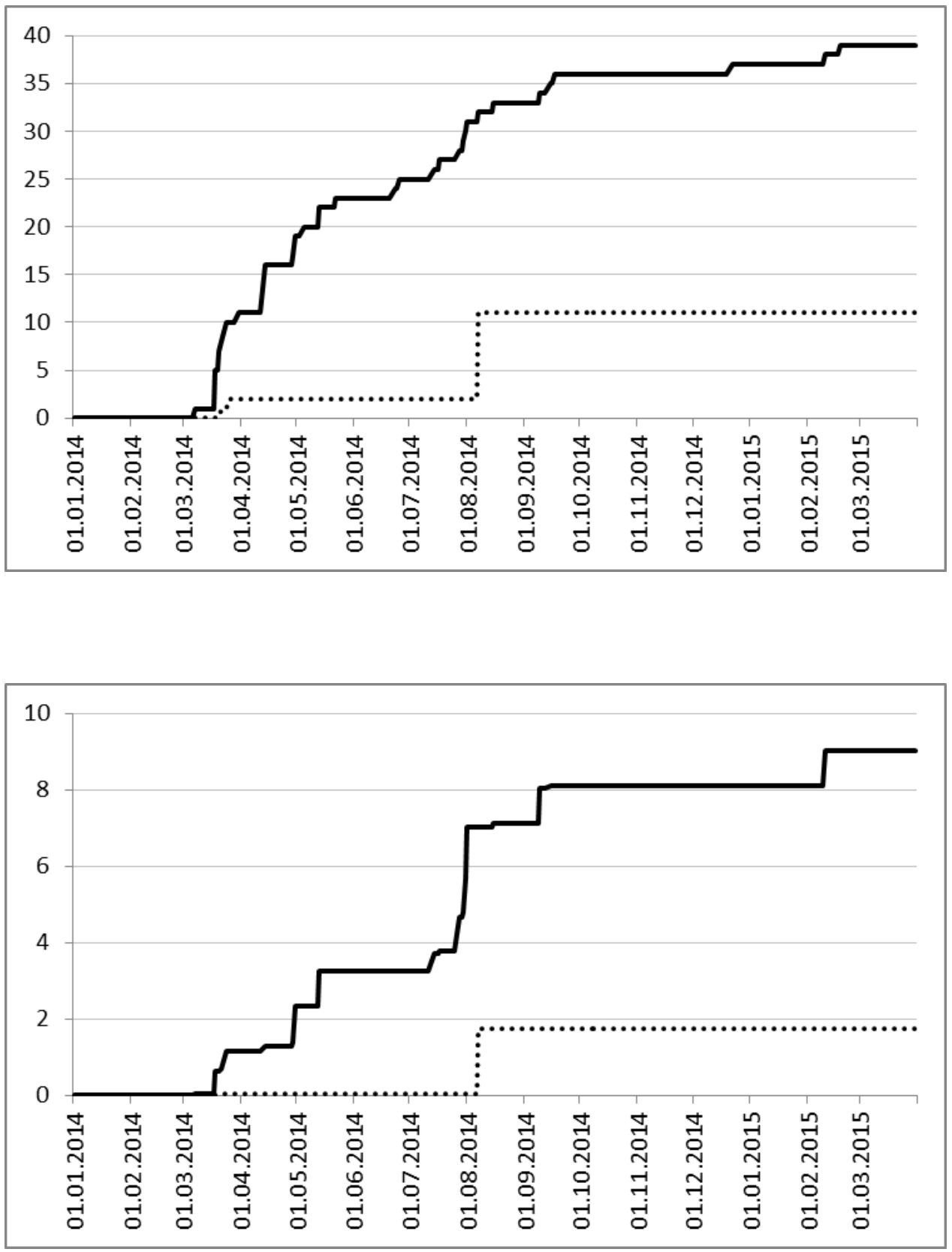

Note: Construction according to equations (1) and (2). Dotted line sanctions from Russia, bold line sanctions against Russia. 
Figure 4: International count media index (keywords "sanctions" and "Russia")

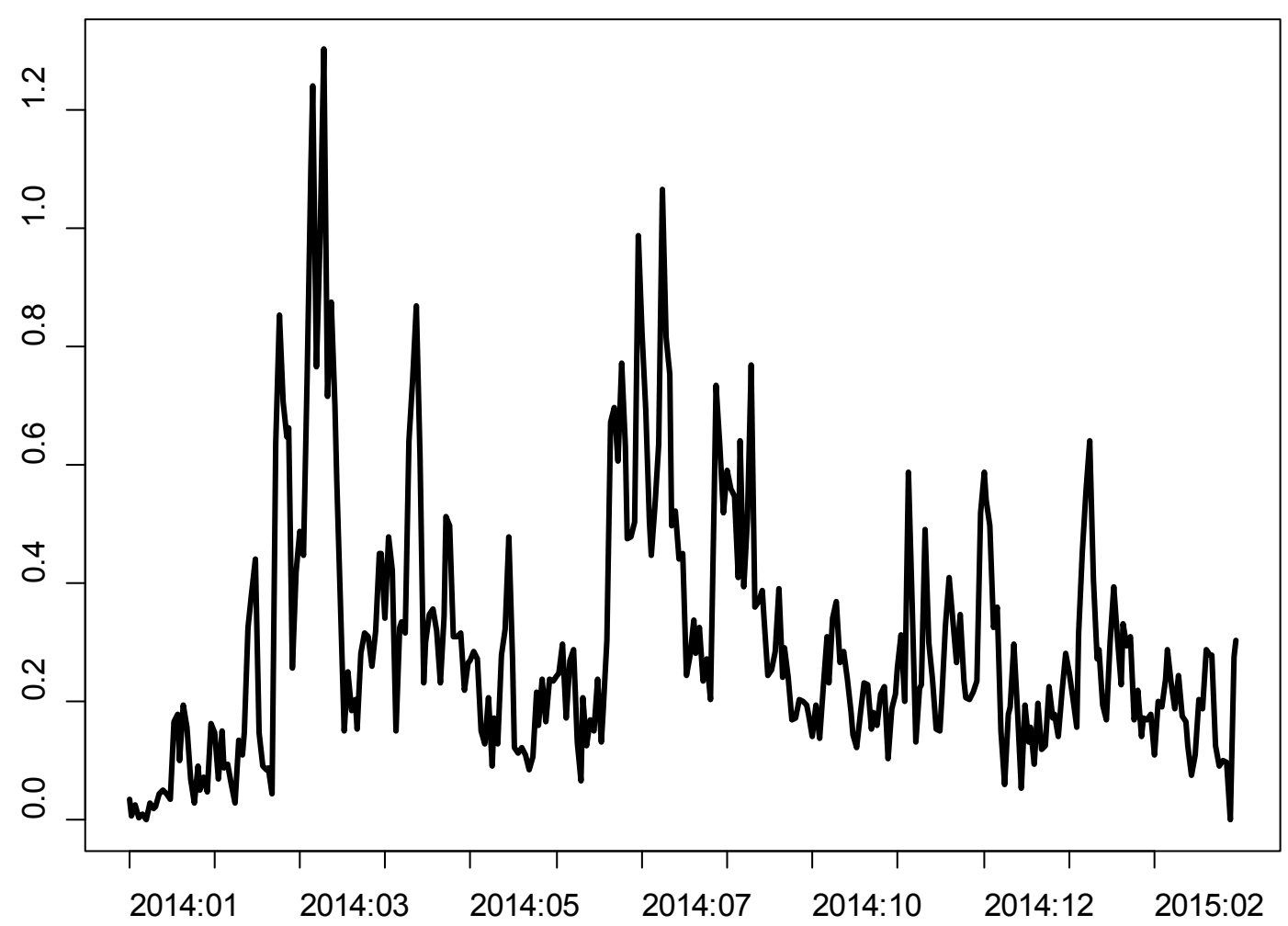


Figure 5: Impulse response analysis

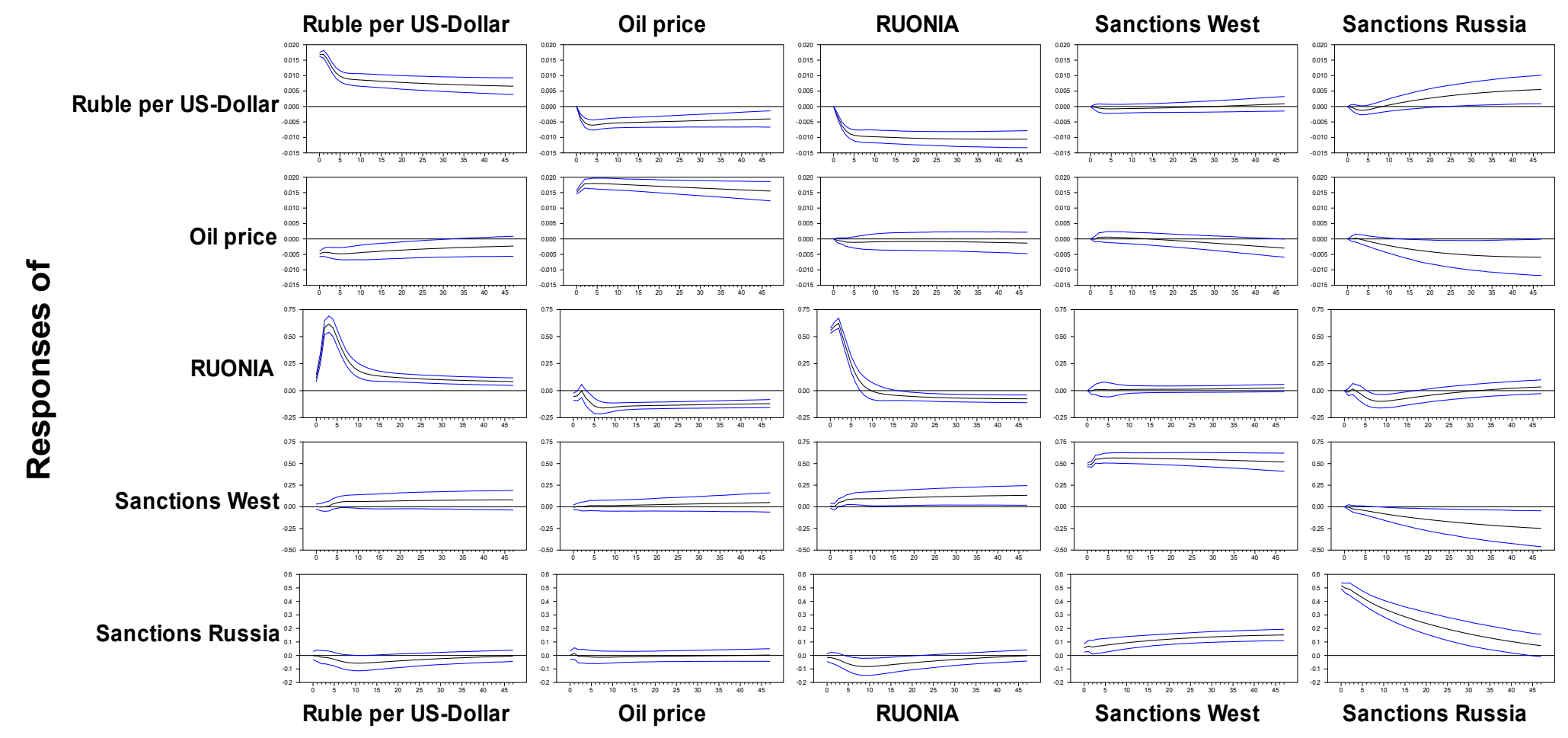

Note: VAR model with 3 lags (AIC) and constant. Rows show responses of variables to shocks in the variables listed in columns. Dotted lines represent 0.68 error bands, obtained by Monte Carlo integration with 2000 draws. 
Table 1. Sanctions implemented by Western countries and Russia

\begin{tabular}{|c|c|c|c|}
\hline \multicolumn{4}{|c|}{2014} \\
\hline Date & Sanctioner & Measure & Weight \\
\hline $3 / 6$ & USA & Blocking property and suspension of entry of not specified persons & 1 \\
\hline $3 / 17$ & USA & Blocking property and suspension of entry of specific persons & 1 \\
\hline $3 / 17$ & EU & Blocking property and suspension of entry of specific persons & 1 \\
\hline $3 / 17$ & Canada & Blocking property and suspension of entry of specific persons & 1 \\
\hline $3 / 17$ & Japan & $\begin{array}{l}\text { Suspension of consultation for relaxing visa regulations, freeze of } \\
\text { certain negotiations (new investment, space cooperation, prevention } \\
\text { of dangerous military activities) }\end{array}$ & 3 \\
\hline $3 / 19$ & Canada & Blocking property and suspension of entry of specific persons & 1 \\
\hline $3 / 19$ & Australia & Blocking property and suspension of entry of specific persons & 1 \\
\hline $3 / 20$ & USA & $\begin{array}{l}\text { Blocking property and suspension of entry of specific persons and of } \\
\text { Rossija Bank }\end{array}$ & 2 \\
\hline $3 / 21$ & Canada & Blocking property and suspension of entry of specific persons/entities & 2 \\
\hline $3 / 21$ & EU & Blocking property and suspension of entry of specific persons & 1 \\
\hline $3 / 28$ & Canada & Blocking property and suspension of entry of specific persons/entities & 2 \\
\hline $4 / 11$ & $\begin{array}{l}\text { Albania, Ice- } \\
\text { land, Mon- } \\
\text { tenegro, Ukrai- } \\
\text { ne }\end{array}$ & Blocking property and suspension of entry of specific persons & 1 \\
\hline $4 / 11$ & USA & Blocking property and suspension of entry of specific persons/entities & 2 \\
\hline $4 / 28$ & USA & Additional restrictive measures on defense exports to Russia & 3 \\
\hline $4 / 29$ & Japan & Suspension of entry of specific persons & 1 \\
\hline $4 / 29$ & EU & Blocking property and suspension of entry of specific persons/entities & 2 \\
\hline $5 / 4$ & Canada & Blocking property and suspension of entry of specific entities & 2 \\
\hline $5 / 12$ & Canada & Blocking property and suspension of entry of specific persons/entities & 2 \\
\hline $5 / 12$ & EU & Blocking property and suspension of entry of specific persons/entities & 2 \\
\hline $5 / 21$ & Australia & Blocking property and suspension of entry of specific persons/entities & 2 \\
\hline $6 / 21$ & Canada & blocking property and suspension of entry of specific persons/entities & 2 \\
\hline $6 / 24$ & Canada & Blocking property and suspension of entry of specific entities & 2 \\
\hline $7 / 12$ & EU & Suspension of entry of specific persons & 1 \\
\hline
\end{tabular}




\begin{tabular}{|c|c|c|c|}
\hline \multicolumn{4}{|c|}{2014} \\
\hline $7 / 16$ & USA & Blocking property and suspension of entry of specific persons/entities & 2 \\
\hline $7 / 25$ & EU & Blocking property and suspension of entry of specific persons/entities & 2 \\
\hline $7 / 29$ & USA & $\begin{array}{l}\text { Additional Treasury sanctions on Russian financial institutions and on } \\
\text { a defense technology entity }\end{array}$ & 3 \\
\hline $7 / 30$ & EU & Blocking property and suspension of entry of specific entities & 2 \\
\hline $7 / 31$ & EU & $\begin{array}{l}\text { Restrictions on exports of certain dual-use goods and technology; } \\
\text { restrictions on the sale, supply, transfer or export of certain technol- } \\
\text { ogies for the oil industry; restrictions on access to capital market for } \\
\text { certain financial institutions }\end{array}$ & 3 \\
\hline $8 / 6$ & Canada & Blocking property and suspension of entry of specific persons/entities & 2 \\
\hline $8 / 14$ & Ukraine & Blocking property and suspension of entry of specific persons/entities & 2 \\
\hline $9 / 12$ & USA & Blocking property and suspension of entry of specific persons & 2 \\
\hline $9 / 16$ & Canada & Blocking property and suspension of entry of specific persons/entities & 2 \\
\hline $9 / 8$ & EU & Blocking property and suspension of entry of specific persons & 2 \\
\hline $12 / 19$ & Canada & $\begin{array}{l}\text { Blocking property and suspension of entry of specific per- } \\
\text { sons/entities; prohibition of exports of oil-related equipment }\end{array}$ & 3 \\
\hline \multicolumn{4}{|c|}{2015} \\
\hline $2 / 9$ & EU & Blocking property and suspension of entry of specific persons/entities & 2 \\
\hline $2 / 17$ & Canada & Blocking property and suspension of entry of specific persons/entities & 2 \\
\hline $3 / 31$ & Australia & $\begin{array}{l}\text { Restrictions on export to or import from Russia of arms and related } \\
\text { materiel; restrictions on export to Russia of certain items for use in } \\
\text { petroleum exploration and production; restrictions on export to Cri- } \\
\text { mea and Sevastopol of certain items for use in the energy and miner- } \\
\text { als sector; restrictions on commercial dealing with certain capital } \\
\text { financial market instruments issued by certain Russian state-owned } \\
\text { entities; restrictions on investment in Crimea and Sevastopol in infra- } \\
\text { structure, transport, telecommunications, energy, oil, gas and miner- } \\
\text { als sectors. }\end{array}$ & 3 \\
\hline
\end{tabular}


Russian sanctions on Western countries

\begin{tabular}{|r|l|l|r|}
\hline \multicolumn{2}{|l|}{2014} & Weight \\
\hline Date & Sanctioner & Measure & 1 \\
\hline $3 / 20$ & Russia & Suspension of entry of specific persons (US citizens) & 1 \\
\hline $8 / 24$ & Russia & Suspension of entry of specific persons (Canadian citizens) & 3 \\
\hline
\end{tabular}


Table 2: Media and search words

\begin{tabular}{|l|l|l|}
\hline Country & Media & Search words \\
\hline France & Le Figaro, Le monde, Les echos & Russie, sanctions \\
\hline Germany & All media from Genios databank & Rußland, Sanktionen \\
\hline Italy & Repubblica & Russia, sanzioni \\
\hline Russia & Gazeta (Газета), Kommersant (Коммерсантъ) & Россия, санкции \\
\hline Spain & АВС, La Vanguardia & Rusia, sanciones \\
\hline Ukraine & Vesti (Вести) & Pоссия, санкции \\
\hline UK & Financial Times, Independent & Russia, sanctions \\
\hline USA & Washington Post & Russia, sanctions \\
\hline
\end{tabular}


Table 3: Cointegration properties

\begin{tabular}{|l|c|c|c|c|c|}
\hline & $\mathrm{H}_{0}: \mathrm{r} \leq 0$ & $\mathrm{H}_{0}: \mathrm{r} \leq 1$ & $\mathrm{H}_{0}: \mathrm{r} \leq 2$ & $\mathrm{H}_{0}: \mathrm{r} \leq 3$ & $\mathrm{H}_{0}: \mathrm{r} \leq 4$ \\
\hline Trace & $71.85(0.032)$ & $34.08(0.502)$ & $13.40(0.871)$ & $4.78(0.879)$ & $0.81(0.369)$ \\
\hline
\end{tabular}

\begin{tabular}{|l|c|c|c|c|}
\hline & \multicolumn{2}{|c|}{ Unrestricted model } & \multicolumn{2}{c|}{ Restricted model } \\
\hline & $\beta$ & $\alpha$ & $\beta$ & $\alpha$ \\
\hline Ruble & 1 & $-0.049(0.008)$ & 1 & $-0.045(0.008)$ \\
\hline Oil price & $1.853(0.297)$ & $0.002(0.008)$ & $1.937(0.223)$ & 0 \\
\hline RUONIA & $0.072(0.013)$ & $-0.503(0.293)$ & $0.079(0.014)$ & $-0.515(0.271)$ \\
\hline Sanctions West & $-0.006(0.003)$ & $0.379(0.248)$ & $-0.005(0.003)$ & 0 \\
\hline Sanctions Russia & $0.018(0.009)$ & $-0.295(0.268)$ & $0.019(0.010)$ & 0 \\
\hline
\end{tabular}

Note: Western (Russian) sanctions are unweighted indices. Lag selection in VAR model with unrestricted constant determined by the AIC and equal to 3. Bartlett corrected trace statistic, $p$-values in parantheses. $\beta$ is the cointegration vector, $\alpha$ the feedback coefficients in the equations of the respective differenced variables. Cointegration vector normalized to the Ruble. Numbers in parantheses denote standard errors. 
Table 4: Variance decomposition of forecast errors

Ruble shock

\begin{tabular}{|c|c|c|c|c|c|}
\hline Steps & Ruble & Oil price & RUONIA & Sanctions West & Sanctions Russia \\
\hline 5 & 77.8 & 8.1 & 13.7 & 0.1 & 0.3 \\
\hline 10 & 61.5 & 11.0 & 27.1 & 0.2 & 0.2 \\
\hline 20 & 49.2 & 12.0 & 37.9 & 0.2 & 0.8 \\
\hline
\end{tabular}

Oil price shock

\begin{tabular}{|c|c|c|c|c|c|}
\hline Steps & Ruble & Oil price & RUONIA & Sanctions West & Sanctions Russia \\
\hline 5 & 6.7 & 93.0 & 0.2 & 0.1 & 0.0 \\
\hline 10 & 6.6 & 92.8 & 0.3 & 0.1 & 0.3 \\
\hline 20 & 5.7 & 92.3 & 0.2 & 0.0 & 1.7 \\
\hline
\end{tabular}

RUONIA shock

\begin{tabular}{|c|c|c|c|c|c|}
\hline Steps & Ruble & Oil price & RUONIA & Sanctions West & Sanctions Russia \\
\hline 5 & 44.3 & 0.8 & 54.8 & 0.0 & 0.1 \\
\hline 10 & 50.5 & 4.0 & 44.2 & 0.0 & 1.2 \\
\hline 20 & 49.4 & 8.7 & 39.4 & 0.1 & 2.5 \\
\hline
\end{tabular}

Western sanctions shock

\begin{tabular}{|c|c|c|c|c|c|}
\hline Steps & Ruble & Oil price & RUONIA & Sanctions West & Sanctions Russia \\
\hline 5 & 0.1 & 0.0 & 0.9 & 98.7 & 0.2 \\
\hline 10 & 0.6 & 0.0 & 1.7 & 96.9 & 0.7 \\
\hline 20 & 1.0 & 0.1 & 2.3 & 94.3 & 2.4 \\
\hline
\end{tabular}

Russian sanctions shock

\begin{tabular}{|c|c|c|c|c|c|}
\hline Steps & Ruble & Oil price & RUONIA & Sanctions West & Sanctions Russia \\
\hline 5 & 0.1 & 0.0 & 0.4 & 1.8 & 97.8 \\
\hline 10 & 0.5 & 0.1 & 1.6 & 2.7 & 95.1 \\
\hline 20 & 1.2 & 0.1 & 2.7 & 5.6 & 90.5 \\
\hline
\end{tabular}

Note: See Figure 3. Numbers in \%. 
Table 5: Conditional variances of VAR errors

\begin{tabular}{|l|l|l|l|l|l|}
\hline & Ruble & Oil price & RUONIA & Sanctions West & Sanctions Russia \\
\hline Constant & $0.002(0.001)$ & $0.001(0.001)$ & $0.005(0.042)$ & $0.090(0.061)$ & $0.000(0.001)$ \\
\hline GARCH Lag & $0.922(0.013)$ & $0.916(0.022)$ & $0.447(0.047)$ & $0.433(0.034)$ & $0.435(0.025)$ \\
\hline ARCH Lag & $0.338(0.031)$ & $0.109(0.043)$ & $-0.584(0.055)$ & $1.284(0.098)$ & $1.699(0.084)$ \\
\hline Media & & $0.009(0.003)$ & & $0.827(0.080)$ & \\
\hline Media(-1) & $-0.005(0.004)$ & $-0.011(0.004)$ & & & \\
\hline Media(-2) & $0.005(0.004)$ & $0.008(0.004)$ & $-0.254(0.160)$ & $-0.267(0.114)$ & $0.034(0.027)$ \\
\hline Media(-3) & & $-0.014(0.004)$ & $0.235(0.169)$ & $-0.737(0.083)$ & \\
\hline Media(-4) & & $0.014(0.004)$ & & $0.716(0.103)$ & $0.053(0.028)$ \\
\hline Media(-5) & & & & $-0.371(0.123)$ & $0.133(0.023)$ \\
\hline
\end{tabular}

Note: Conditional variances obtained from multivariate $\operatorname{GARCH}(1,1)$ model. Conditional covariance matrix estimated by BEKK method (Engle and Kroner, 1995). To foster convergence, preliminary simplex iterations are performed. Standard errors in parentheses. 